\title{
Pattern of Retrogression of Native Vegetation in North Central Oklahoma
}

\section{PHILLIP L. SIMS AND DON D. DWYER}

Graduate Research Assistant and Assistant Professor ${ }^{1}$ respectively, Agronomy Department, Oklahoma State University, Stillwater.

\section{Highlight}

The pattern of retrogression due to grazing for native vegetation was established for the important plants of the loamy prairie range site. Total forb numbers increased as range condition declined but there were usually as many perennial forbs in high condition pastures as in low condition ones. Total available water was significantly greater in excellent condition than poor condition range.

Disturbance of plant cover by overuse, such as grazing and mowing, upsets orderly succession and causes retrogression (Sampson 1919). Ellison (1960) states that overgrazing initiates a destructive type of secondary succession resulting in a change in the vegetative composition and establishment of plant communities that are usually less palatable to the grazing animal and ordinarily are less productive. Range condition needs to be studied in order to relate range condition to productivity which may be related to animal output and rancher income.

Range condition is a practical representation of the major successional stages of plant communities as influenced by grazing use. The sustained trend associated with retrogression is the primary factor causing a decline in range condition. Major factors considered in trend are density and composition of the vegetation and litter and stability of the soil. Composition of the vegetation denotes the quality of the

1 Dwyer presently Associate Professor, Range Management, New Mexico State University, University Park. range and is the best indicator of long time trends (Parker 1954).

Basal cover increases as overgrazing occurs, when the increasing species are sod-formers, and is accompanied by a decrease in plant vigor and forage production (Tomanek and Albertson 1953).

Several workers (Launchbaugh 1955, Weaver and Tomanek 1951, Voight and Weaver 1951, and Smith 1940) have studied vegetative changes due to grazing and found that certain groups of species decrease in abundance while other species increase or invade. Dyksterhuis (1946), charting the change in vegetation due to overgrazing in the Fort Worth Prairie, found that decreasers declined from 67 percent on excellent condition range to less than two percent on poor condition pastures. Increasers rose from three percent on excellent condition range to 88 percent on fair condition sites, then decreased as overuse continued. Invader plants increased from two percent on excellent condition range to 47 percent on poor condition range.

A decline in range condition is usually accompanied by a decrease in the amount of mulch which also indicates that recent use has been abnormally heavy (Humphrey 1949). Much emphasis has been placed on the effect of soil surface condition on plantwater relationship. Duley and Kelly (1941) and Duley and Domingo (1949) state that surface condition of the soil is more important than soil type or previ- ous soil moisture on rate of intake of rainfall. Mulch conserves moisture primarily in the upper two feet of the soil according to Stephenson and Schuster (1945).

The primary purpose of this study was to determine the pattern of retrogression that occurs on the loamy prairie range site in north central Oklahoma. Also an attempt was made to determine the relationship between condition of the range and amount of soil moisture.

\section{Methods and Procedures}

Investigation of the retrogression pattern of native vegetation was conducted on the loamy prairie range site, the dominant grassland site in north central Oklahoma. Study areas were selected to represent various stages of vegetative departure from the potential of the site. Care was taken to avoid sites that had ever been cultivated. Yearlong grazing was practiced on all areas.

The loamy prairie range sites are gently to steeply rolling, deep, loamy upland soils. The soils are neutral to slightly acid with slow to medium permeability (U.S.D.A. Soil Conserv. Serv. 1961).

The climate of the study region includes hot, often dry summers; mild autumns; mild to cold winters and cool springs. Average annual precipitation for the study region is 32.2 inches (U.S. Dept. of Commerce). Approximately 70 percent of the total precipitation occurs from April to October.

The point intercept method of vegetation analysis (Levy and Madden 1933) was used to determine the percent basal cover and percent species composition of the grasses of each study area. Two hundred samples, 2,000 points, were taken in each study area.

The square foot method was used to determine the abundance and species of forbs present on each study area. Fifty square foot samples were taken in each study area at regular intervals along predetermined transects. The square foot sampling tool was placed at the toe on the final pace and the number of plants of each species occurring in the sample was recorded.

The quantity of mulch was determined by collecting all mulch from 
Table 1. Relative percent of decreaser, increaser, and invader grasses and percent basal cover of grasses in the study areas.

\begin{tabular}{|c|c|c|c|c|c|c|c|c|c|c|c|c|c|c|}
\hline \multirow[t]{2}{*}{ Item } & \multicolumn{14}{|c|}{ STUDY AREAS } \\
\hline & $\overline{I^{*}}$ & II & III & IV $^{*}$ & $\mathrm{~V}$ & VI & VII & VIII & IX & $\mathrm{X}$ & $\mathrm{XI}$ & XII & XIII & XIV \\
\hline Decreasers & 93 & 88 & 86 & 82 & 81 & 75 & 57 & 27 & 26 & 12 & 6 & 3 & 1 & - \\
\hline Increasers & 7 & 8 & 12 & 15 & 16 & 21 & 35 & 29 & 39 & 30 & 43 & 5 & 11 & 40 \\
\hline Invaders & - & 4 & 2 & 3 & 4 & 4 & 8 & 44 & 34 & 57 & 51 & 92 & 88 & 60 \\
\hline TOTAL & 100 & 100 & 100 & 100 & 101 & 100 & 100 & 100 & 99 & 99 & 100 & 100 & 100 & 100 \\
\hline Basal Cover & 13 & 12 & 8 & 14 & 16 & 10 & 15 & 16 & 13 & 23 & 16 & 23 & 20 & 19 \\
\hline Range Condit & & EX & E L & $\mathrm{EN}^{\prime}$ & & $\mathrm{G}$ & OD & FA & & & & $00 \mathrm{~F}$ & & \\
\hline
\end{tabular}

*Native Hay Meadows

twenty 11.5 by 24 inch quadrats. Each sample was oven-dried and the weight recorded in grams. Pounds of mulch per acre were calculated by multiplying the average weights in grams by the factor 50. Frequency of mulch occurrrence was determined in conjunction with species composition determination by the point intercept method. A hit was recorded when a pin came in contact with mulch, but had not touched a plant.

Soil moisture measurements on two pastures that differed widely in vegetative composition were taken with a Nuclear Chicago probe (P-19) and scaler (No. 2,800). Percent soil moisture by volume was determined at six inch intervals to a depth of four feet. These determinations were made twice monthly from April 1 to October 1 and monthly during the remaining six months of the study.

\section{Results and Discussion}

\section{Range Condition and Grass Composition}

A definite trend can be seen in the change in composition of decreaser, increaser and invader grasses on the various study areas as vegetation retrogression occurs (Table 1).

The decreasers, little bluestem (Andropogon scoparius) ${ }^{2}$, big bluestem ( $A$. gerardi), indiangrass (Sorghastrum nutans) and switchgrass (Panicum virgatum) comprised 93 percent of the grasses in study area I and decreased to zero in area XIV.

2 Scientific names follow Waterfall, U. T. 1960. Keys to the Flora of Oklahoma. Okla. State Univ. Bot. Dept. and Res. Foundation.
Of the seven species of increaser grasses only blue grama (Bouteloua gracilis), sideoats grama (B. curtipendula) and hairy grama (B. hirsuta) were important. These along with tall dropseed (Sporobolus asper), Scribners panicum (Panicum oligosanthes), purple lovegrass (Eragrostis spectabilis), fall witchgrass (Leptoloma cognatum) and Carex spp. increased from seven percent in study area I to an average of 33 percent in study areas VI through XI.

Invader grasses increased from a trace of buffalograss (Buchloe dactyloides) in area I to aproximately 90 percent in pastures XII and XIII. A decrease of invaders in pasture XIV is a result of an unexplainable increase of blue grama.

As range condition declined basal area of grasses increased (Table 1). This was a result of the increase in buffalograss and blue grama. The average basal cover of the five excellent condition pastures was 12 percent as opposed to an average of 20 percent basal cover for grasses in the five poor condition pastures.

Table 2 illustrates the changes that occurred between study area I, a lightly used meadow, and study area XIV, a severely overgrazed pasture. The study areas are arranged in order of successively poorer range condition from I to XIV.

Little bluestem was the most abundant decreaser species, big bluestem the second most abund- ant. Sites I and IV (meadows) had less big bluestem than sites II, III, VI, and VII (grazed pastures), indicating that mowing a native meadow may be detrimental to big bluestem. The native hay meadows were the only excellent condition areas having any buffalograss. Big bluestem declined from approximately 18 percent of the composition in areas II and III to 0.3 percent in the poor condition range, area XIV. Big bluestem was present in the two poorest pastures but little bluestem was not. This suggests that big bluestem may resist continuous severe overgrazing better than little bluestem. The large percentage of big bluestem in areas VI and VII, 34.2 and 15.2 percent, respective$1 y$, is difficult to explain except both areas had a past history of over-utilization; however, for the last few years prior to the study they had been lightly grazed. It is possible that big bluestem recovers more quickly than some other species after overutilization and that the present cover reflects recent light use rather than past heavy use.

Indiangrass was relatively unimportant except in the meadows. Annual mowing seemed to cause an increase in the abundance of this grass. Indiangrass and switchgrass disappeared in the poor condition pastures.

Sideoats grama was a relatively common species in many of the pastures, especially the good and fair condition pastures as 
Table 2. Changes in grass composition due to grazing and mowing. Percent species composition.

\begin{tabular}{|c|c|c|c|c|c|c|c|c|c|c|c|c|c|c|}
\hline & \multicolumn{14}{|c|}{ STUDY AREAS } \\
\hline & $I *$ & II & III & IV* & $\mathrm{v}$ & VI & VII & VIII & IX & $\mathrm{X}$ & $\mathrm{XI}$ & XII & XIII & XIV \\
\hline \multicolumn{15}{|l|}{ DECREASER SPECIES } \\
\hline Andropogon scoparius & 72.9 & 70.1 & 62.9 & 58.7 & 69.6 & 35.3 & 39.7 & 20.8 & 17.2 & 5.8 & 1.6 & 0.8 & - & - \\
\hline Andropogon gerardi & 10.6 & 17.3 & 18.8 & 7.6 & 7.4 & 34.2 & 15.2 & 5.0 & 8.0 & 5.8 & 4.2 & 2.1 & 0.5 & 0.3 \\
\hline Sorghastrum nutans & 8.4 & 0.4 & 3.5 & 15.1 & 3.3 & 5.8 & 1.3 & 0.3 & 1.1 & 0.2 & - & - & - & - \\
\hline Panicum virgatum & 0.7 & 0.4 & 0.6 & 0.6 & 0.3 & - & 0.3 & 0.9 & - & 0.4 & - & - & - & - \\
\hline TOTAL DECREASERS & 92.6 & 88.2 & 85.8 & 82.0 & 80.6 & 75.3 & 56.5 & 27.0 & 26.3 & 12.2 & 5.8 & 2.9 & 0.5 & 0.3 \\
\hline \multicolumn{15}{|l|}{ INCREASER SPECIES } \\
\hline Bouteloua curtipendula & 4.5 & 4.4 & 0.6 & 2.8 & 7.4 & 13.7 & 20.9 & 10.5 & 10.6 & 11.2 & 21.2 & 3.0 & 1.3 & - \\
\hline Bouteloua gracilis & 0.1 & 0.4 & - & 1.3 & 0.3 & 1.0 & 0.7 & 1.2 & 10.6 & 9.9 & 12.7 & 0.2 & 3.0 & 33.0 \\
\hline Bouteloua hirsuta & 0.3 & - & - & 7.2 & 3.0 & 1.6 & 5.3 & 4.0 & 11.0 & 6.7 & 5.3 & - & 5.3 & 6.2 \\
\hline Sporobolus asper & 1.0 & 1.2 & 5.9 & 0.6 & 0.3 & 1.6 & 2.6 & 0.9 & 1.9 & 0.2 & 0.6 & 0.2 & - & - \\
\hline Carex spp. & 0.3 & - & 2.9 & 0.9 & 0.7 & 1.6 & 1.3 & 2.2 & 1.0 & 0.4 & 2.2 & 1.3 & 1.5 & 0.6 \\
\hline Panicum oligosanthes & 0.2 & - & - & 0.6 & 1.6 & - & 1.7 & 1.2 & -1 & - & 0.6 & - & - & - \\
\hline Eragrostis spectabilis & 0.4 & 2.0 & 2.9 & 0.6 & 0.7 & 1.0 & 0.7 & 2.8 & - & 0.2 & - & 0.2 & 0.2 & - \\
\hline Leptoloma cognatum & - & 0.4 & - & 0.9 & 1.5 & - & 1.7 & 5.8 & 4.2 & 1.3 & 0.6 & - & - & - \\
\hline TOTAL INCREASERS & 7.3 & 8.4 & 12.3 & 14.9 & 15.5 & 20.5 & 34.9 & 28.6 & 39.3 & 29.9 & 43.2 & 4.9 & 11.3 & 39.8 \\
\hline \multicolumn{15}{|l|}{ INVADER SPECIES } \\
\hline Buchloe dactyloides & 0.1 & - & - & 0.9 & - & 2.6 & 4.6 & 13.0 & 13.7 & 37.7 & 15.2 & 70.5 & 69.3 & 48.4 \\
\hline Setaria geniculata & - & - & - & - & - & - & 0.3 & 0.5 & 2.3 & - & - & - & 0.5 & - \\
\hline Andropogon saccharoides & - & 2.0 & - & 0.6 & - & 1.6 & 0.3 & 3.0 & 2.7 & 13.4 & - & 2.1 & 0.2 & - \\
\hline Andropogon virginicus & - & - & - & - & - & - & 0.3 & 3.3 & 1.5 & - & - & - & - & - \\
\hline Eragrostis curtipedicellata & - & - & 1.2 & 0.3 & - & - & - & - & - & - & - & 0.2 & - & - \\
\hline Chloris verticillata & - & 0.8 & 0.6 & - & - & - & 0.3 & 6.4 & 2.7 & 5.2 & 18.0 & 12.4 & 4.3 & 1.0 \\
\hline Agrostis hiemalis & - & - & - & 0.3 & 1.1 & - & - & - & - & - & - & - & 1.0 & - \\
\hline Aristida oligantha & - & - & - & - & 0.7 & - & 0.3 & 14.5 & 9.9 & 0.4 & 8.7 & 0.6 & 5.3 & 7.3 \\
\hline Aristida purpurescens & - & - & - & - & 0.7 & - & - & - & -1 & - & - & - & - & - \\
\hline Bromus faponicus & - & - & - & - & 0.3 & - & - & - & - & - & - & - & - & 0.3 \\
\hline Paspalum spp. & - & 0.4 & - & 0.6 & 0.7 & - & 2.3 & 2.4 & 1.5 & 0.6 & 7.4 & 6.2 & 7.1 & 2.9 \\
\hline Poa arachnifera & - & - & - & - & - & - & $\therefore$ & 0.6 & - & - & 0.9 & - & - & - \\
\hline Hordeum pusillum & - & - & - & - & - & - & - & - & - & - & - & - & - & 0.3 \\
\hline Distichlis stricta & - & - & - & - & - & - & - & - & - & - & - & - & 0.2 & - \\
\hline Eragrostis intermedia & - & - & - & - & - & - & - & 0.5 & - & - & 0.3 & - & - & - \\
\hline TOTAL INVADERS & 0.1 & 3.2 & 1.8 & 2.7 & 3.5 & 4.2 & 8.4 & 44.2 & 34.3 & 57.3 & 50.5 & 92.0 & 87.9 & 60.2 \\
\hline RANGE CONDITION & $E X$ & C E & L L & E N & $\mathrm{T}$ & G 0 & $O D$ & F A & I $\mathrm{R}$ & $\mathbf{P}$ & 0 & 0 & $\mathrm{R}$ & \\
\hline
\end{tabular}

* Native Hay Meadows

well as areas $\mathrm{X}$ and $\mathrm{XI}$ of the poor condition pastures. This species was quite variable, but averaged about 14 percent in the intermediate condition pastures (areas VI through XI). Blue grama became a prominent increaser in the fair condition pasture IX and in the poor condition pastures, XI and XIV. The reaction of this plant to the severest grazing pressure studied was not clear.

Invader grasses of importance, other than buffalograss, were annual threeawn (Aristida oligantha), silver bluestem (Andropogon saccharoides) and windmill grass (Chloris verticillata). Many of the invader grasses, as well as some increaser grasses, showed no apparent pattern or trend due to grazing pressure and resulted in fluctuations in species composition.
Effects of Grazing on Forbs

Forbs were important in many of the study areas while in others they were relatively insignificant (Table 3). Western ragweed (Ambrosia psilostachya) tended to increase with a decline in range condition. An exception to this was pasture II, which even though lightly grazed, had an abundance of western ragweed in areas of "spot" overgrazing. Other perennial species that tended to increase were western yarrow (Achillea lanulosa), blackeyedsusan (Rudbeckia hirta), wavyleaf thistle (Cirsium undulatum) and Baldwin ironweed (Vernonia baldwinii). Perennial species that showed a decrease as grazing pressures increased were blue salvia (Salvia azurea) and prairie scurfpea (Psoralea tenuiflora).
Annual forb species increased in most cases under progressively heavier grazing. Such species as spurge (Euphorbia supina), marestail (Conyza canadensis), and Plantago spp. did not be come important until pastures retrogressed to fair or poor condition. Annual broomweed ( $\mathrm{Gu}$ tierrezia dracunculoides) became more abundant in pastures VII through XI, but when range utilization was severest in pastures XIII and XIV, this species diminished.

Total forb numbers increased as range condition declined. However, Table 3 indicates there may be as many total perennial forbs in the very best pastures as in the very poorest. Forbs, especially the annuals, appear to react to seasonal weather changes and grazing practices more quickly than the grasses. 
Table 3. Numbers of perennial and annual forbs per square foot in the various study areas.

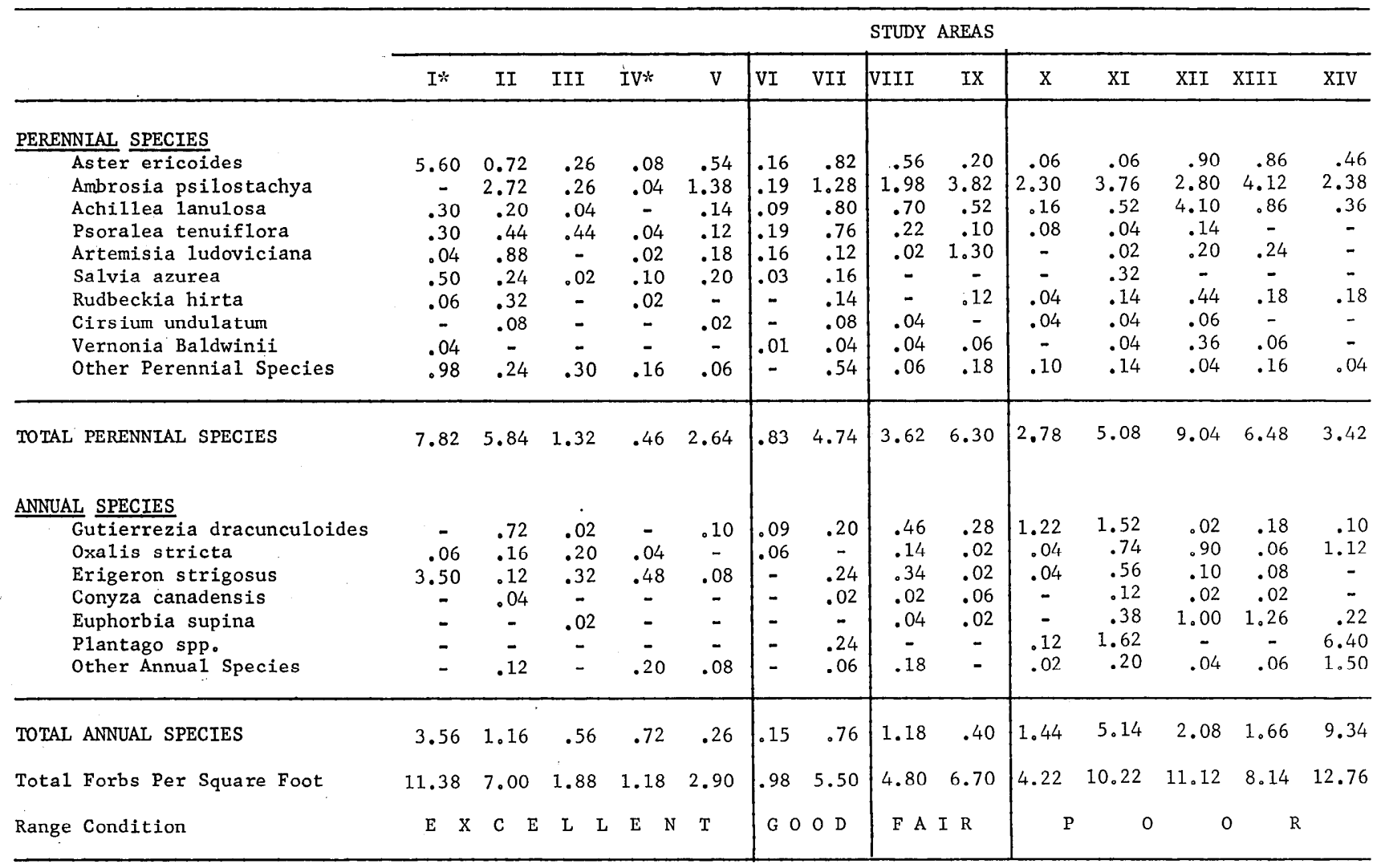

* Native Hay Meadows

Table 4. Quantity of mulch on the study areas in pounds per acre and percent basal cover of mulch.

\begin{tabular}{|c|c|c|c|c|c|c|c|c|c|c|c|c|c|c|}
\hline \multirow[t]{2}{*}{ Item } & \multicolumn{14}{|c|}{ STUDY AREAS } \\
\hline & $\mathrm{I}^{*}$ & II & III & IV $^{*}$ & $\mathrm{~V}$ & VI & VII & VIII & IX & $\mathrm{x}$ & $\mathrm{XI}$ & XII & XIII & XIV \\
\hline Mulch Quantity & 1890 & 2430 & 5860 & 1485 & 2480 & 5145 & 1920 & 835 & 1430 & 263 & 240 & 800 & 261 & 81 \\
\hline Mulch Cover & ** & ** & 82 & 57 & 56 & 86 & 15 & 24 & 52 & 3 & 10 & 37 & 7 & 4 \\
\hline Range Condition & \multicolumn{5}{|c|}{ EXCELLENT } & \multicolumn{2}{|c|}{ GOOD } & \multicolumn{3}{|c|}{ FAIR } & \multicolumn{3}{|c|}{ POOR } & \\
\hline
\end{tabular}

*Native Hay Meadows

**No data

\section{Mulch as Related to Range Condition}

There was considerably less mulch present in volume and ground cover in poor as compared to excellent condition pastures (Table 4). The data indicate that the average mulch is over one ton per acre in the excellent condition pastures and about 1,000 pounds per acre in the fair condition pastures. In severely overgrazed pastures mulch was very limited. Percent of ground covered by mulch was related to pounds of mulch per acre.

The amount of mulch on a range site appeared subject to rapid change; for example, in area III, which was overutilized after the sampling, mulch was reduced to less than one ton per acre in one year.

\section{Effect of Range Condition on Soil Moisture}

Study areas III and XIII were used to determine the effect of range condition on soil moisture. Pasture III was in excellent range condition and pasture XIII in poor. A detailed examination of each soil profile immediately adjacent to the source of the soil moisture data indicated that the only difference in the profiles occurred at depths greater than 30 inches where the soil texture in pasture III contained more of the sand fraction than in pasture XIII.

Figure 1 shows the inches of available water in excellent and 


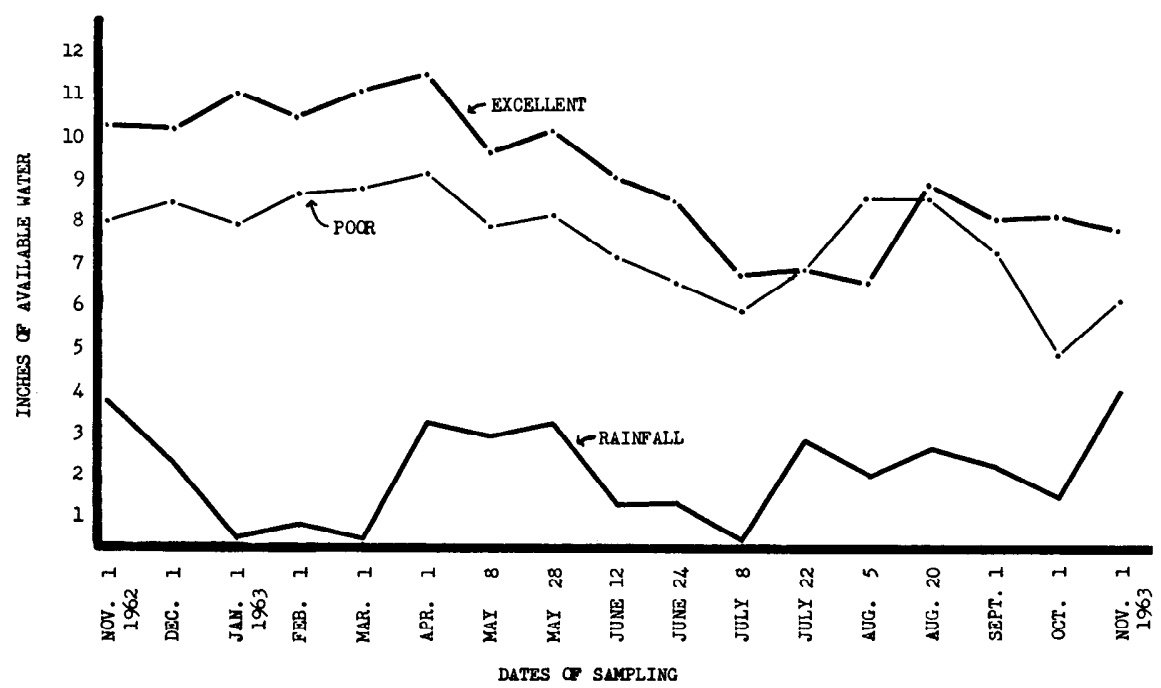

Figure 1. Available soil moisture in 48 inch profile of excellent and poor range condi. tion sites and rainfall data.

poor condition pastures throughout the year, and the precipitation for the interval between sampling. Overall, soil moisture in the excellent condition pasture exceeded the moisture in the poor condition by an average 1.8 inches of water available to plants in the 48 inch profile (difference significant at the .05 level). However, no moisture stress was observed in either pasture during a near average rainfall year of 29.4 inches.

Throughout the dormant period, November, 1962, to April, 1963 , the poor condition pasture contained fewer inches of available water in the profile than the excellent condition pasture. Once plants began to make their spring growth, water in both profiles declined even though substantial rainfall occurred in April and May. The soil in the excellent condition pasture had more inches of available water than the poor condition pasture and probably more water used due to more vegetation being present. As range condition declined from excellent to poor, pounds of mulch and percent of ground covered by mulch decreased from 5,860 pounds and 82 percent to 261 pounds and seven percent, respectively. According to Duley and Kelly
(1941) and Duley and Domingo (1949), this decrease in mulch covering could influence the amount of rainfall absorbed into the soil profile.

\section{Summary}

The pattern of retrogression due to grazing for native vegetation was determined for the loamy prairie range site in north was made to determine the relationship of range condition to amount of mulch on the soil surface and to soil moisture. The loamy prairie range sites are gently rolling, deep, loamy upland soils. The soils are neutral to slightly acid with slow to medium permeability.

The important findings were:

(1) Decreasers, primarily little and big bluestem, declined from 93 percent in excellent condition pastures to zero in extremely poor condition pastures.

(2) Sideoats grama, blue grama, and other increaser plants increased in intermediate condition pastures and usually decreased in poor condition pastures.

(3) Invader plants, primarily buffalograss, increased from zero on excellent condition pastures to 92 percent on a poor condition pasture. central Oklahoma. An attempt
(4) Basal cover of grasses increased from 12.5 percent in excellent and good condition pastures to 14.5 percent in fair condition pastures and to 20 percent in poor condition pastures.

(5) Forbs were important in many study areas and in others they were insignificant. Western ragweed, western yarrow, blackeyed susan, and wavyleaf thistle are perennial species that increased with overgrazing. Blue salvia and prairie scurfpea decreased when overgrazed. Generally, perennial forbs decreased under light grazing but increased as grazing became heavier while annual forbs increased under overgrazing.

(6) Considerably less mulch occurred on poor condition pastures as compared to excellent and good condition sites. Average mulch per acre was 3,000 pounds for excellent and good, 1,130 for fair and 330 pounds for poor range condition study areas. Percent of ground covered by mulch decreased with lowering range condition and reduction in mulch quantity.

(7) Throughout a season of near average rainfall, 29.4 inches, available water averaged 9.3 and 7.5 inches per 48 inch profile for excellent and poor range condition pastures, respectively.

\section{LITERATURE CITED}

Beutner, E. L. AND D. Anderson. 1943. The effect of surface mulches on water conservation and forage production in some semidesert grassland soils. Jour. Amer. Soc. Agron. 35: 393-400.

Duley, F. L. and C. E. Domingo. 1949. Effect of grass on intake of water. Nebr. Res. Bul. 159. 15 pp.

Duley, F. L. and L. L. Kelly. 1939. Effect of soil type, slope, and surface conditions on intake of water. Nebr. Res. Bul. 112. 16 pp.

Duley, F. L. AND L. L. KELLY. 1941. Surface condition of soil and time of application as related to intake of water. U. S. Dept. Agr. Cir. $608.31 \mathrm{pp}$.

Dyksterhuis, E. J. 1946. The vegetation of the Fort Worth Prairie. Ecol. Mono. 16:1-29.

Ellison, Lincoln. 1960. The influence of grazing on plant succession of rangelands. Bot. Rev. 26:1-78. 
Humphrey, R. R. 1949. Field comments on the range condition method of forage survey. Jour. Range Mangt. 2:1-10.

LAUNCHBAUGH, J. L. 1955. Vegetational changes in San Antonio Prairie associated with grazing, retirement from grazing and abandonment from cultivation. Ecol. Mono. 25: 39-57.

LeVY, E. L. ANd E. A. Madden. 1933. The point method of pasture analysis. New Zealand Jour. Agr. 46: 267-279.

PARKer, K. W. 1954 Application of ecology in the determination of range condition and trend. Jour.
Range Mangt. 7:14-23.

Sampson, A. W. 1919. Plant succession in relation to range management. U. S. Dept. Agr. Bul. 791. $76 \mathrm{pp}$.

Smith, C. C. 1940. The effect of overgrazing and erosion upon the biota of the mixed grass prairie of Oklahoma. Ecol. 21:381-397.

Stephenson, R. E. and C. E. SchusTER. 1945. Effect of mulches on soil properties. Soil Sci. 59:219-230.

Tomanek, G. W. and F. W. Albertson. 1953. Some effects of different intensities of grazing on mixed prairies near Hays, Kansas. Jour. Range Mangt. 6:299-306.
U. S. Departiment of Commerce, Weather Bureau. Climatological Data, Oklahoma.

U. S. Department of Agriculture, SoIl Conservation Service. 1961. Oklahoma range site technical descriptions.

Voight, J. W. aNd J. E. Weaver. 1951. Range condition classes of midwestern pasture: an ecological analysis. Ecol. Mono. 21:39-60.

Weaver, J. E. and G. W. Tomanek. 1951. Ecological studies in a midwestern range: the vegetation and effects of cattle on its composition and distribution. Nebr. Cons. Bul. $31.82 \mathrm{pp}$. 